Universiteit

Leiden

The Netherlands

\title{
Eleanor Roosevelt's autofabrication as gendered premediation of a female presidency
}

Polak, S.A.; Fazzi, D.; Luscombe, A.

\section{Citation}

Polak, S. A. (2020). Eleanor Roosevelt's autofabrication as gendered premediation of a female presidency. In D. Fazzi \& A. Luscombe (Eds.), The World of the Roosevelts (pp. 171-192). Cham: Palgrave Macmillan.

doi:10.1007/978-3-10.1007\%2F978-3-030-42315-5_9030-42315-5_9

Version: $\quad$ Publisher's Version

License: $\quad$ Licensed under Article 25fa Copyright Act/Law (Amendment Taverne)

Downloaded from: $\quad$ https://hdl.handle.net/1887/3245425

Note: To cite this publication please use the final published version (if applicable). 
The World of the Roosevelts

\author{
Series Editor \\ David B. Woolner \\ The Roosevelt Institute \\ New York City, USA
}


This longstanding series has published high-quality monographs and edited collections related to the presidencies of Franklin Roosevelt for nearly two decades. Combining economic, political, diplomatic, social, and intellectual history, it constitutes a comprehensive, multi-faceted exploration of a pivotal era in American and global history.

More information about this series at http://www.palgrave.com/gp/series/14319 
Dario Fazzi • Anya Luscombe Editors

\title{
Eleanor Roosevelt's \\ Views on Diplomacy and Democracy
}

\author{
The Global Citizen
}

palgrave

macmillan 
Editors

Dario Fazzi

Roosevelt Institute for

American Studies

Middelburg, The Netherlands
Anya Luscombe

Utrecht University

Middelburg, The Netherlands

The World of the Roosevelts

ISBN 978-3-030-42314-8 https://doi.org/10.1007/978-3-030-42315-5

ISBN 978-3-030-42315-5 (eBook)

(C) The Editor(s) (if applicable) and The Author(s), under exclusive licence to Springer Nature Switzerland AG 2020

This work is subject to copyright. All rights are solely and exclusively licensed by the Publisher, whether the whole or part of the material is concerned, specifically the rights of translation, reprinting, reuse of illustrations, recitation, broadcasting, reproduction on microfilms or in any other physical way, and transmission or information storage and retrieval, electronic adaptation, computer software, or by similar or dissimilar methodology now known or hereafter developed.

The use of general descriptive names, registered names, trademarks, service marks, etc. in this publication does not imply, even in the absence of a specific statement, that such names are exempt from the relevant protective laws and regulations and therefore free for general use. The publisher, the authors and the editors are safe to assume that the advice and information in this book are believed to be true and accurate at the date of publication. Neither the publisher nor the authors or the editors give a warranty, expressed or implied, with respect to the material contained herein or for any errors or omissions that may have been made. The publisher remains neutral with regard to jurisdictional claims in published maps and institutional affiliations.

This Palgrave Macmillan imprint is published by the registered company Springer Nature Switzerland AG.

The registered company address is: Gewerbestrasse 11, 6330 Cham, Switzerland 
For Leonardo, Elise and Imme.

May you all in life "do the thing you think you cannot do." 


\section{CONTENTS}

Introduction

Dario Fazzi and Anya Luscombe

The Great National and Transnational Communicator:

Eleanor Roosevelt's Use of Radio to Promote Peace and Understanding

Anya Luscombe

“Mrs. Roosevelt Goes on Tour": Eleanor Roosevelt's Soft Diplomacy During World War II

Raffaella Baritono

Eleanor Roosevelt in Yugoslavia Between Wedge Strategy and Cold War Internationalism

Carla Konta

Behind the Iron Curtain: Eleanor Roosevelt's Visit to Poland in 1960

Halina Parafianowicz

Liberalism Meets Radicalism: Eleanor Roosevelt and the Internationalization of the Black Liberation Struggle Tim Kies 
Dancing Barefoot and Politicizing Dance at the White House: Eleanor Roosevelt and Martha Graham's Collaboration During the Rise of Fascism in Europe

Camelia Lenart

"I Know What You Are Doing for Other People Too": Dutch Journalist Mary Pos Reaches Out to Eleanor Roosevelt Babs Boter

Eleanor Roosevelt's Autofabrication as Gendered Premediation of a Female Presidency

Sara Polak

Eleanor Roosevelt and the Nature: Bridging Conservationism with Environmentalism

Dario Fazzi

Index 


\section{Notes on Contributors}

Raffaella Baritono (Department of Political and Social Sciences, University of Bologna, raffaella.baritono@unibo.it) teaches US history and politics. She has published extensively on US political culture and institutions, with particular reference to women's political history, American liberalism, American state, social sciences, and politics. She is the author of Eleanor Roosevelt. Una storia americana (Il Mulino, forthcoming).

Babs Boter (Vrije Universiteit Amsterdam, b.boter@vu.nl) is Assistant Professor at the faculty of humanities where she teaches literatures in English (travel writing, world literature). She is writing a biography of the Dutch travel journalist Mary Pos (1904-1987) and is also initiator and convener of an international and interdisciplinary research group called Unhinging the National Framework: Platform for the Study of LifeWriting and Transnationalism. Boter has a background in history (Leiden University), American studies (University of Minnesota), and cultural studies (Amsterdam School for Cultural Analysis, University of Amsterdam) and has worked for humanities programs at various Dutch and American universities.

Dario Fazzi (Roosevelt Institute for American Studies, d.fazzi@zeeland. $\mathrm{nl}$ ) is a historian of US social and foreign policy history. In particular, he is interested in public intellectuals' and social movements' impact on US Cold War relations. His main field of research lies in peace history and transatlantic history. $\mathrm{He}$ is the author of Eleanor Roosevelt and the 
Anti-Nuclear Movement: The Voice of Conscience (Palgrave, 2016) and has published articles, book chapters, and reviews on nuclear culture, peace movements, youth protests, transatlantic crossings, and base politics.

Tim Kies (Leiden University, kiestim@hotmail.com) holds an M.A. in US social history. He is particularly interested in black Americans' long struggle for freedom. His main field of research lies in the history of nineteenth-century US slavery.

Carla Konta (University of Rijeka, ckonta@uniri.hr) is a historian of US foreign relations, the Cold War, and socialist Yugoslavia. She is the author of US Public Diplomacy in Socialist Yugoslavia, 1950-70: Soft Culture, Cold Partners (2020). Her research interests focus on governmental and nongovernmental linkages between the US and Yugoslavia, including public diplomacy and international relations, and, recently, on Yugoslav nuclear civilian program, scientists, and activism. Her articles and chapters appeared in Contemporanea; West Croatian History Journal; The Legacy of J. William Fulbright: Policy, Power and Ideology (2019); and Cabiers du Monde Russe.

Camelia Lenart (State University of New York at Albany, ilenart@albany. edu) is a historian whose work is at the interface of diplomatic, dance, and women history. Focusing, in particular, on the embodiment of American cultural diplomacy during the Cold War, she analyzes the role played by the State Department in Martha Graham's European tours. Lenart's work-published in journals and edited books-was supported by fellowships and awards, including an Andrew W. Mellon Fellowship from University College London. Her article "Dancing Politics Beyond the Iron Curtain: Martha Graham's 1962 Tour to Yugoslavia and Poland" won the prestigious Dance Chronicle Founding Editors' Award.

Anya Luscombe (Utrecht University, a.luscombe@ucr.nl) is Associate Professor of Media at University College Roosevelt, where she teaches Rhetoric and Journalism, and affiliated researcher at Utrecht's Department of Media and Culture Studies. Her research interests include radio history, cultural history, and Eleanor Roosevelt. She is the author of BBC Radio News, from the Swinging Sixties to the Turbulent Noughties (2013) and has published articles, book chapters, and reviews on media, (transnational) broadcasting, and women's history. She is a former BBC journalist and has 
been a Fulbright scholar at Bard College, New York, and a research fellow at the Dutch Institute of Sound and Vision in Hilversum.

Halina Parafianowicz (Faculty of History and International Relations, halka@uwb.edu.pl) is Full Professor of World History at the University of Bialystok. She was a Fulbright Fellowship recipient, which resulted in a biography of Eleanor Roosevelt, Eleanor Anna Roosevelt (1884-1962). In the Shadow of the Great Husband (2000). Her research focuses on American political history and diplomatic relations between the US and Central Europe in the twentieth century. She has published books and articles on cultural and diplomatic relations between the US and Poland and Czechoslovakia during the interwar period as well as on other topics related to American diplomacy, modern presidency, and first ladies.

Sara Polak (Leiden University Centre for the Arts in Society, s.a.polak@ hum.leidenuniv.nl) is Assistant Professor of American Studies, focusing on US presidents and their media. She wrote This Is Roosevelt's World: FDR as a Cultural Icon in American Memory (2020) and co-edited Embodying Contagion: The Viropolitics of Horror and Desire in Contemporary Discourse (2020) and Online Vitriol: On the History, Affect and Effects of Violence and Trolling on Social Media (2020). She focuses on Trump's use of Twitter. Polak teaches American literature and regularly comments on US politics and culture in Dutch media. 


\title{
Q
}

\section{Eleanor Roosevelt's Autofabrication as Gendered Premediation of a Female Presidency}

\author{
Sara Polak
}

Eleanor Roosevelt was not keen on being called a feminist, and although she definitely took up many feminist causes, she also held on to principles that could be considered old-fashioned even in the 1940s. ${ }^{1}$ Eleanor Roosevelt was among the most influential women in American history, but at the same time would often in her communication stress her wifely role. As First Lady, she began to organize her own press conferences exclusively for women reporters, but also regularly insisted on the importance of domesticity and motherhood for women. For instance, in her advice column in the Ladies Home Journal, she advised a young woman working in the war industry not to prioritize work over family: "Since you married him, I should think a baby was something you would both want." 2 Eleanor Roosevelt's insinuation that it was impossible for the letter writer to prefer putting off having a baby, even while the letter writer explicitly writes that she does prefer this, shows her tendency in this instance toward Victorian morality, at least in the context of the Ladies Home Journal. Although the

\footnotetext{
S. Polak $(\bowtie)$

Leiden University Centre for the Arts in Society, Leiden, The Netherlands e-mail: s.a.polak@hum.leidenuniv.nl

(C) The Author(s) 2020

D. Fazzi, A. Luscombe (eds.), Eleanor Roosevelt's Views on Diplomacy and Democracy, The World of the Roosevelts, https://doi.org/10.1007/978-3-030-42315-5_9
} 
letter writer says: "My husband is all for having a baby right away, but I want to keep on with my job until the war is over," Roosevelt stresses that having a baby is an only, perhaps the only, reasonable and appropriate ambition "since you married him." Simultaneously, she often acted upon what seems to have been a fairly radical feminist agenda: because of her female-only press conferences, news media had to retain White House reporter positions for women throughout the Depression. Moreover, Roosevelt dedicated a great deal of time and attention to supporting women's initiatives and educating women, particularly regarding political activism and global politics broadly, using a wide range of forms and media, including magazines, radio programs, and television shows for housewives.

One might argue that there is a discrepancy between Eleanor Roosevelt's somewhat old-fashioned discourse with regard to gender and her highly progressive practice. This could be considered a form of "tactics from the subjugated," except that Roosevelt of course was hardly truly subjugated, certainly not during and after Franklin Delano Roosevelt's (FDR's) presidency. ${ }^{3}$ The people she helped empower often were, but Eleanor Roosevelt herself actually marshaled rather a lot of influence on politics, arguably indeed more than she should have had, because she did not formally have a public function, nor had she been elected to political office. Playing down the extent of her power, particularly as First Lady, was thus also a necessity. Rhetorically posing as traditionally feminine-modest, reticent, deferential—she tended to cast her positions and actions as unthreatening. She did contribute to the wider public debate, for example, after the USA's initial engagement in World War II, when she defended her husband's position; and she also at times opposed his political choices. She no doubt followed her own convictions in this, which were different from his policies, but in so far as she publicized her dissent or support, Roosevelt was careful and measured.

The purpose of her "My Day" column (that ran six days a week from the end of 1935 to 1962), certainly initially, was ostensibly not to discuss politics, but rather to relate her own everyday life and experiences as First Lady. Particularly in the column's early days, Eleanor usually did manage not to get dragged into politics. ${ }^{4}$ Her performance of domesticity and modesty gave her considerable space to act independently, particularly in the margin of what was seen as politically important or sensitive, both within Franklin Roosevelt's administrations and after his death as a public intellectual, diplomat, and delegate to the United Nations. 
In this combination of reticent domesticity-often understood as shyness-and often-successful activism, Roosevelt's public writing was one of the main ways she performed as domestic. Her activism was at least equally present, but it was less visible in the public perception. Indeed, Roosevelt's more activist interventions were often highly invisible, or at least, her role remained invisible to the public. This invisibility of Roosevelt's influential activism in the context of public and foreign policy, and the clear visibility of her homely writing, has led many Eleanor Roosevelt historians to the position that she has not been done enough justice in cultural remembrance. Jo Binker and Brigid O'Farrell, of the George Washington University "My Day" project which made a large portion of Eleanor Roosevelt's papers digitally accessible, expressed their disappointment, for instance, that Ken Burns' 14-hour PBS documentary The Roosevelts: An Intimate History (2014), spent less time on her life and achievements than on her husband's and uncle's:

As a savvy producer and consumer of television, Eleanor Roosevelt would have been the first to appreciate Burns's series on her family. She would have welcomed his interest in their lives and accomplishments but she would have been puzzled and dismayed at the amount of time devoted to her private life. [...] Eleanor Roosevelt's contributions are often overlooked and undervalued. ${ }^{5}$

Clearly, the assumption here is that Eleanor Roosevelt would be "puzzled and dismayed" that her private life did not receive enough attention, but there are many instances in which she expressed reticence about her private life and explicitly stressed that she did not consider it interesting or appropriate to direct a great deal of public attention to this aspect of her existence. Although the criticism that Eleanor Roosevelt's contributions have been "overlooked and undervalued" is fair, especially compared to Franklin and Theodore Roosevelt's, this effect should also be understood as a result of Eleanor Roosevelt's successful self-presentation and invisible exercise of political power. If she would indeed have been dismayed at the lack of attention given to her by the series, the seemingly overlooked work in the public sphere would be at issue, rather than her private life.

As Blanche Wiesen Cook and others have shown, however, there is a great deal of evidence that Eleanor Roosevelt, even if she denied this, enjoyed her active involvement in politics. ${ }^{6}$ Indeed, a key manner in which she played the game of politics was to present herself strategically to allow 
other interested parties to overlook and undervalue her influence. This was, as I shall discuss, with reference to Cynthia Enloe's model of how international relations are invisibly negotiated, particularly successful in foreign policy. ${ }^{7}$ This chapter, therefore, analyzes the gendered genealogy and afterlife of Eleanor Roosevelt's role in American foreign policy.

\section{Genealogy of a Political Career on the Edge OF THE ESTABLISHMENT}

In the 1920s, in the years after Franklin Roosevelt had suffered polio and was starting to build up his political career again despite no longer being able to walk unassisted, Eleanor Roosevelt first entered the public arena. She did so to substitute for her husband before he was ready to perform publicly. Coached intensively by her husband's right hand, Louis Howe, she got onto the campaign trail and embarked on a wide range of public speaking engagements. Although she at first feared and loathed being at the center of public attention, she soon started to enjoy public speaking. During the same period in which Franklin Roosevelt was learning to cope with disability, she learned the ropes of key parts of his public role, acquired enthusiasm for that role, and developed her talent for it. ${ }^{8}$

The argument has often been put forward, both by historians and others, that the time between 1918, when Eleanor found out that her husband was having an affair with Lucy Mercer, and 1924, when FDR for the first time after his illness took to the national political stage again, was crucial to both his and her personal development. ${ }^{9}$ They seem certainly to have been formative for Eleanor Roosevelt, who famously commented on her discovery of Franklin's affair that "the bottom dropped out of my particular world, and I faced myself, my surroundings, my world, honestly for the first time." ${ }^{10}$ What precisely Eleanor Roosevelt "fac [ed] honestly" remains implicit, but the suggestion is that she came to perceive herself to have lived within a fiction of harmony without realizing it. She seems to describe a fall into consciousness regarding the implicit but insidious, and gendered power relation, guiding "her particular world." This fall into consciousness made her aware of the political reality of her world, and her place of limited but also usable power within it.

Eleanor Roosevelt assumed a novel independence which had to be integrated with her somewhat old-fashioned performance of femininity, in order to deal with the culturally sensitive incongruity between autonomy 
and gendered expectations. When one thinks of her political activism as a function of how her marriage became a mutually advantageous partnership on an explicitly political level—or as something that was necessitated by her husband's disability — the role can easily seem something that forced itself upon her. However, she had also been raised with a strong penchant for progressive activism, which came to the fore well before any marital discord. In any case, Roosevelt regularly positioned herself as having taken on a very visible position despite her natural inclinations. FDR's personal assistant Louis Howe, who in 1921 became intensely aware of the need to have a mobile Roosevelt operate literally in the name of the one in polio rehabilitation, was a key figure in coaching Eleanor to occupy a mature position as an independent agent beside FDR. Such factors contributed to spurring Eleanor Roosevelt on to learn to juggle her femininity with a public role and increasing political clout.

Autofabrication is a term to complement Stephen Greenblatt's notion of self-fashioning. ${ }^{11}$ Whereas self-fashioning pertains primarily to how selves were fashioned in interaction with their environment, autofabrication refers to the process in which a leader's public image (rather than self) is shaped, by this person and their entourage. Self-fashioning concerns the making of an individual self, driven both by the person involved and by environmental pressures and circumstances, which are shaped in turn by cultural and ideological demands. Self-fashioning as a concept works well to consider the fashioning of most selves, but to theorize the making of iconic political leaders, it is necessary to take into account the fact that political leaders embody and exert great power, and that they, in modern democratic systems, represent their electorate. Thus, they are under pressure to project themselves as relatable public icons that a diverse audience can identify with, which can function to obscure their exertion of power. FDR exemplified success in autofabrication, as his largely celebratory remembrance attests. ${ }^{12}$ Eleanor Roosevelt was a crucial agent in FDR's autofabrication and, because she survived him and remained publicly active and visible, of his legacy. She became especially important to his autofabrication because of her adeptness at expanding his influence, informally and indirectly, into spaces such as the domestic sphere, entertainment sections of mass media, and also, beyond his death. Eleanor Roosevelt amplified FDR's autofabrication by expanding his reach into areas not habitually considered the realm of presidential leadership.

Limiting the concept of autofabrication to elected political leaders would mean that Eleanor Roosevelt could not have had her own 
autofabrication. However, as one of the agents in FDR's autofabrication, and particularly after his death, she effectively and covertly used her own informal power-as if he were still president, and she the person with access to his wishes - while simultaneously presenting a consistent public image, visible but also stressing her modesty. Eleanor Roosevelt, for instance, used her deceased husband's lingering authority when shewhile she had previously always signed off as "Eleanor Roosevelt" — started to sign letters and columns with "Mrs. Franklin D. Roosevelt." In a similar way, she used her name and authority during the McCarthy era to extend her protective chairmanship to organizations that were at risk of being targeted as potentially having communist sympathies. ${ }^{13}$ Thus, although autofabrication as a term refers specifically to leaders who hold formal power over and formally represent their subjects, Eleanor Roosevelt did actualy have real power, if not formally, and so she did not merely help create her husband's public image, but simultaneously worked on her own gendered autofabrication. Unlike in formal, and male, leaders' autofabrication, invisibility and a display of modesty were important.

One illustrative instance of Roosevelt's ambiguous stressing of her own modesty occurred in a "My Day" column in which she reviews the opening night of Dore Schary's play Sunrise at Campobello, a dramatic narration of FDR's illness with polio and initial rehabilitation ("My Day," February 4, 1958). Regarding the play's dramatic representation of herself, Eleanor Roosevelt writes: "Miss Mary Fickett did an excellent job of being a very sweet character, which she is in the play. I am afraid I was never really like Mr. Schary's picture of myself, so I could even look upon the portrayal of myself in a fictional light!" 14 When calling the actress' representation of herself "very sweet," while denying that she ever was "really like" that, Eleanor distances herself from the representation in the play, without giving away what she was "really like." In doing so, she hints at her own modesty, and assertively refuses that cutesy view of herself. She seems to endorse the idea that sweetness is a positive trait, but also implicitly declares herself impervious to that compliment within the negotiation of power. Attending the play's opening night and positively reviewing it, however, in itself already lends weight and a hint of veracity to the play. Sunrise at Campobello was adapted as a successful film in 1960, nominated for four Academy Awards, and won a Best Actress Golden Globe Award for Greer Garson's role of Eleanor Roosevelt. Within Sunrise at Campobello's universe, the Eleanor Roosevelt character is crucial to the narrative's success; outside of that universe, the real Eleanor Roosevelt 
enabled its making. She mentioned in a column in June 1960 that the filming was "in full swing" at the main house and her private cottage at Hyde Park - thus once more advertising and officiously authorizing it.

Endorsing Sunrise at Campobello, and especially her remark about Fickett's "sweetness," exemplifies how Eleanor Roosevelt, through her role as agent of her husband's autofabrication, also attended to her owninsinuating that she was too modest to call herself sweet, and hinting at something sharper than the fictional rendering as sweet. However, the fact that this remains so diffuse in the end functions both to stress Eleanor Roosevelt's mysteriousness and her elusive power. On paper, Eleanor Roosevelt had no more political power than any other American citizen, but in reality, she held a great deal of political influence, both through her husband and in his name. During the FDR administrations, the Democratic Party often enlisted her help to keep in the fold particular parts of its constituency on the more radical left wing in exchange for small or symbolic concessions to groups Eleanor Roosevelt particularly advocated for, and her willingness to engage in such deals often meant party officials would not be forced to address controversial or otherwise politically sensitive issues. $^{15}$

This meant that many politicians and other leaders informally "owed" Eleanor Roosevelt favors, and after Franklin Roosevelt's death, her voice also came to implicitly inherit some of his authority. Many of Roosevelt's citations of what her husband would have said or wanted carried the suggestion of wifely deference, when in fact she used his name and presumable views to suit her own needs. For instance, in the "My Day" column of June 16, 1953, she expresses criticism at the USA's use of the atomic bomb against Japan in 1945, and the usual arguments to defend the use of the bomb: "It is useless to say that Germany started the war and began the research which we were then obliged to take over and which led to the discovery of the atom bomb." This was a firm conviction Eleanor Roosevelt held from right after the events onward. Since Franklin Roosevelt had the atomic bomb developed, it is by no means clear he would have agreed with her, or prevented its use. But Eleanor, following the passage above, refers to Franklin's desolation after Pearl Harbor to denounce the use of the atomic bomb on Hiroshima ("I can remember only too well my husband's feeling and the feeling of the people of the U.S. when we first heard of Pearl Harbor. [...] Out of all this came Hiroshima. [...] As one contemplates Hiroshima, one can only say God grant to men greater wisdom in the future."). ${ }^{16}$ Thus, she implicitly equates Pearl Harbor (which every 
reader would be presumed to deplore, like Franklin Roosevelt) with Hiroshima. FDR died before Hiroshima was bombed, but there is little evidence that he considered doing so a lack of wisdom. Eleanor Roosevelt cleverly avoids speculating about this, but her at the time extremely controversial critique of the use of the bombs is given weight through FDR's presidential authority. Simultaneously, it is toned down by the humility expressed in her deferrence to her husband's presumable feelings.

Still, in suggesting that FDR might have disapproved of the atomic attack on Hiroshima, Eleanor Roosevelt "borrowed" some of his authority, continuing a pattern in which she had been one of his communication channels into places FDR was physically unable to access, or areas of society and public opinion making that were not the president's natural terrain. After FDR's death, Eleanor Roosevelt's continuing representation of course no longer supported him politically, but it often did contribute to his celebratory remembrance. But what was more important: it did contribute to Eleanor Roosevelt's own authority and influence, while it kept up her carefully built public image of modesty, even though, of course, after 1945, she began to accept public positions, and was thus responsible for her own actions.

Another key manner in which Eleanor Roosevelt expanded the reach of Franklin's autofabrication, as well as her own, was through operating as the writer and narrator of his nomos. Nomos, a term which Robert Cover defined as a "normative universe," revolves around the constant process of creating and maintaining "a world of right and wrong, of lawful and unlawful, of valid and void." 17 As the leader of the federal government's executive branch, FDR was deeply involved in the creation and maintenance of the American nomos on a political and legal level, and one might indeed argue that he changed it for the decades to come. Although he did not have the formal powers of legislation or jurisdiction, his visions and decisions regulated and ordered American society and lives around the world. More than other presidents, he reframed the relationship between citizens and the government, both through his media communication and by changing drastically what kinds of concrete support American citizens might expect from the government. He was both in the executive and in the dramatic sense of the word the lead actor, though simultaneously, he needed to consider the desirability of displaying his power. Eleanor Roosevelt's narrative of the nomos the President inhabited and participated in shaping was a vehicle, among other things, for displaying some and occluding other elements of this dynamic. Eleanor Roosevelt effectively 
became the narrator of the nomos FDR produced and sustained, increasingly so over time, and she continued to act as the agent of his nomos and of his legacy after his death.

Eleanor Roosevelt filled the gap left by her husband through writing. Franklin Roosevelt spoke and acted-appropriately for an executive and a dramatic actor. He left a large amount of voice recordings and a library filled with personal and public paper trail of his life and presidency, but he actually wrote little; indeed, he often avoided note-taking during meetings with cabinet members or staff. His signature was primarily performative, an act to transform a formulaic text into law-if he wrote, it was not in a narrative sense. Eleanor Roosevelt, in contrast, wrote a lot of narrative memoir, and when she signed off her writings with her name, in her own handwriting, this had the effect of stressing the personal nature of her writing. Winston Churchill was both a major actor in and a narrator of World War II; Franklin Roosevelt, however, did not write the history of the war or any event during his presidency, and in a sense passed on that role to Eleanor. ${ }^{18}$ She took this up with fervor through her daily columns, monthly pieces in a wide range of magazines, and a total of four autobiographies. One may understand Franklin Roosevelt's disinterest in leaving narrative writing or any memoir as part of his modernity and his preference for mass media-radio, photography, newsreels-but at the same time, Eleanor Roosevelt's writing did contribute proverbially to his immortality. She actively took forward the issues and ideals of his nomos through narrative.

Eleanor Roosevelt's writing can be read as contributing to Franklin's autofabrication, but it is clearly part of a double deal: by enabling his public image to reach new (largely female-gendered, domestic) realms, Eleanor Roosevelt also built a massive platform for herself. Her narrative voice became a household article with unprecedented authority throughout the Western world. Politically, she also functioned to connect Franklin's centrism with the much more radically progressive wing of the Democratic Party. ${ }^{19}$ The public persona she honed over time continued to relate back to her role representing FDR, often to lend authority to her own positions, while suggesting appropriate deference to a male leader's perception. Nonetheless, Roosevelt assertively argued her own positions on national and international issues, thus educating and informing American audiences with a relatively large distance from the machinations of international politics. In that shape, and channeled through the well-known voice of the USA's longtime First Lady, whom Harry Truman later dubbed 
"First Lady of the World," Eleanor Roosevelt's words were received as unthreatening and yet commanding respect. This reception, and Roosevelt's astuteness in catering to the silent expectations and needs of formal stakeholders within foreign policy, suggests that Eleanor Roosevelt did actually autofabricate, but, through the use of gender and gender expectations, she could, at least to citizens with a reasonable distance from the process of politics, come across as less of a politician than she really was.

\section{The Logic of Premediation: Eleanor Roosevelt's Foreshadowing of Future Feminist Issues}

Richard Grusin, who, together with Jay Bolton, coined the term remediation to refer to new media's logic of redesigning older media forms and genres, ${ }^{20}$ a few years later theorized the notion of premediation. ${ }^{21}$ Premediation refers to the way in which events, particularly since 9/11, often are premediated in advance, following a range of potential scenarios, so that when they do happen, they are always already a remediation. Grusin links this need for constant premediation to anxiety caused by $9 / 11$ about the shock of the unexpected that marks terrorism. However, he also stresses that premediation has been around for much longer, and often also functions to make possible and imaginable certain scenarios, as various films premediating 9/11 (Independence Day [1996], Armageddon [1998]) in fact did. Franklin and Eleanor Roosevelt both seemed to lend themselves, and be interested in, the possibility of functioning as a premediation, and propelling either themselves or their political causes into the future, by explicitly imagining this and offering premediations of potential futures to others.

Eleanor Roosevelt's performative positioning as an activist on the edge of the establishment during her husband's presidency, and after his death as a public official in the arena of international politics, can be understood in the context of Cynthia Enloe's paradigmatic Bananas, Beaches, Bases: Making Feminist Sense of International Politics (1990). ${ }^{22}$ Enloe's study expanded the perspective of international politics beyond its traditional focus on powerful white men who control the complex workings of global international politics. She argued that to grasp the massive and seemingly unalterable apparatus of world order, the focus must be expanded to include tourists, chambermaids, prostitutes, military wives at foreign 
bases, and all others who have little formal power but are impacted by and are part of the worldwide choreography of international politics.

The key question "Where are the women in international politics?" is productive because it offers a perspective on international politics that is not limited to official institutional centers of power. The place of women globally supporting the international political system as secretaries, wives, and chambermaids seems so natural and unalterable, also to themselves, that the people involved are in perfect harmony with patriarchic ideology, unaware of their contribution. Since Enloe made this argument, some female American politicians have reached positions of great formal power in international politics-Madeleine Albright, Hillary Clinton, Condoleezza Rice-in part maybe as an effect of increased awareness of the culturally constructed character of an apparatus that once seemed unchangeable or even predestined. However, Eleanor Roosevelt's presence as a force in international politics is both a precursor and a premediation to Enloe's ideas. At the same time, she firmly supported the patriarchic nomos created and maintained by her husband, and she also used her grasp of her value to that nomos to maximize her influence. Moreover, by making a woman in charge of international politics imaginable, she functioned, through her position, also as a paradigmatic enabler to future, more formally established, power positions of women such as Albright, Clinton, and Rice.

Enloe's research convincingly shows that military wives were vital to the success, perceived legitimacy, and continued existence of many bases. However, groups of military wives only started to claim recognition of this in the 1980s; until then, their crucial contribution had been taken for granted by themselves as well as by the male military leadership. ${ }^{23}$ According to Enloe, this presumption of wifely support is essential for male leaders. What her analysis lays bare is essentially an internalized conviction that female contributions ought to be invisible sacrifices made out of devotion and borne in silence, rather than requiring compensation in money or power on an equal footing with men. The book radically pulls into the light the indispensable contributions of women, often made from marginalized or disempowered positions. This shows both their agency and their unused room for negotiation.

Enloe expanded what was perceived as the realm of politics to show the potential for the empowerment of those who are not or only marginally involved in decision-making. Eleanor Roosevelt had a somewhat similar agenda in the way she took politics into spheres where it was usually less 
prominent. She did this in a manner far less pronounced or radical than Enloe, but she comprehended on a profound level that other spheres than the traditionally political could influence political decision-makers. Unlike Enloe, Eleanor Roosevelt, instead of wanting to radically redistribute power, used the political invisibility of her gender and traditional spheres of operation to covertly exercise power. By operating informally, on the edge or outside of politics, she employed her power to contribute to the enfranchisement of women, laborers, and minorities, by helping them in civically and medially symbolic ways, though still outside of traditional politics.

Thus, Eleanor Roosevelt, in practice, shared Enloe's vision that influence could be used from marginal and seemingly non-political spheres, particularly the domestic, that is, that the realm of politics was larger than it is commonly perceived to be. However, Roosevelt employed her invisibility during the White House years to help the marginalized, rather than exposing it as a problem, reinforcing the status quo. As such, she came to use the gaps Franklin left her to fill, both to his and to her own advantage and to the advantage of some of the causes she supported. From that position she could arrange for black contralto Marian Anderson to perform at the Lincoln Memorial in Washington, DC, in 1939. This was both a great symbolic act in the, at that time, slow-moving emancipation of African Americans, and simultaneously, it was indeed symbolic, and did little to concretely increase the political influence of African Americans. As such, she could be argued to have placed many of the people she tried to help in a similar position to her own: not directly powerful, but located so that indirect influence might be exerted while also supporting the status quo.

Her own limited empowerment and way of using the space she had alerted her to the complex expectations of American femininity. In her "My Day" column on August 13, 1942, she wrote about the heroic work of women trying to preserve the "prewar world" while their husbands were absent. She quoted at length from a text on a statue of the Pioneer Woman, a quintessentially American archetype:

the line in the inscription which I like best: "And with all she lived with casual unawareness of her value to civilization."

There we have the secret which should be driven home to every woman. In countless homes in this country today, there are women who are "casually unaware" of the great accomplishments which are theirs. They will be recognized by history, but today we forget them because they do their daily 
tasks so casually that their heroism and the vital place which they fill in our world passes almost unnoticed, and certainly unsung in the present. ${ }^{24}$

What is laudable about the frontier woman-who Eleanor Roosevelt affirms remains highly relevant in 1942-is her "casual unawareness" of her contribution and accomplishment for society. Women are crucial but do not command, or get, their due reward in money or power, and to Eleanor Roosevelt, this unawareness and undemanding attitude is appropriate, indeed ladylike. The frontier woman's modesty and the casual nature of her accomplishment is itself part of her "value to civilization." Roosevelt by no means spurs the women "in countless homes" on to demand recognition of the "great accomplishments which are theirs"; to the contrary, she celebrates their selflessness. However, she does explicitly stress that they "fill a vital place" at home and in wartime jobs left vacant by men, and moreover asserts that "their heroism" will be "recognized by history." It "passes almost unnoticed" because women's heroism, for Eleanor Roosevelt, must include their renunciation of any claim to recognition in the present, but she argues future narratives will not allow women's heroism to go "unsung." Thus, she suggests, that although women may receive little material recognition within the normative universe they inhabit, they will not escape the attention of future narrative. Whether or not this is really the case-Roosevelt's own contributions to American history and culture tend to be underrepresented as Binker and O'Farrell deplore in their review of Ken Burns' documentary The Roosevelts: An Intimate History (2014) - the suggestion is that a modest place in the narrative and a marginal, but not powerless, position in the nomos is suitable for the blueprint of the American woman.

Importantly, Roosevelt also notes that this casual unawareness is "the secret which should be driven home to every woman," alerting readers publicly to the value of women's contribution, while simultaneously stressing the importance of hiding it. Thus, she points out that most women have many uncashed checks, and at the same time she praises their generosity in not demanding recompense. This was a strategy she used in negotiating power herself: if she did require concrete compensations, she did so, characteristically, not for herself, but for the groups and goals she came out to support. In the expanded understanding of the political sphere proposed by Enloe-which included groups and interests not traditionally regarded as part of that realm-Eleanor Roosevelt thus did claim political power, while disguising this fact at the same time. 


\section{Eleanor Roosevelt's Casual Unawareness in Cultural Memory}

In the representations of the Roosevelts that exist in American popular culture, their informal and personal style continues to be celebrated, and Eleanor Roosevelt's penchant to act as an off-the-cuff presidential substitute is a key element of this dynamic. Even her clever ways of directing attention to some issues and avoiding others, her manner of allowing FDR an unofficial second voice, to own or distance himself from as he saw fit, is in itself reflected in cultural memory. The movie Hyde Park on Hudson (2012) contains various examples of this: throughout the film viewers are led to suspect that the Eleanor character takes the initiative to serve hotdogs to the British King and Queen to humiliate them by forcing them to publicly eat a vulgar snack associated with American Independence Day. ${ }^{25}$ As a result, Eleanor is depicted as secretly politically active and rebellious in the emotive margin of otherwise pragmatic and rational international politics. However, in the end, it is insinuated that the hotdogs were FDR's idea after all and that he deliberately used his wife's reputation in order to deflect suspicion away from himself. The historical event now known as the "Hot Dog Summit" of June 11, 1939, was, according to David Woolner, planned in detail by FDR, including the hot dogs. ${ }^{26}$ Whether or not there is evidence to believe that he attempted, as he does in the film, to suggest that the hot dogs were his wife's devious plan, it is exemplary of an actual as well as a popularly remembered dynamic between them.

A key effect of casting Eleanor Roosevelt as an officious voice alongside FDR's official one, especially with her introduction of domesticity into the public icon, is that Franklin and Eleanor Roosevelt, in autofabrication and later, in public remembrance, have remained extremely successful as the nation's projected parents. The broad knowledge that during the presidency they shared no sex life is no problem here-indeed for the popular imagination, this might be considered an advantage. They already did have five children, and so they had clearly had a sexual relationship in the past, and the lack of eroticism between them opened up the potential to fantasize about sexual relationships they may each have had with others, while at the same time, they remained real parents and successfully functioned as symbolic parents to the nation.

This remembrance of the Roosevelts as a presidential couple whose officious acts and expressions are intertwined with their public policies and administration is echoed and (re)produced in Doris Kearns Goodwin's 
paradigmatic No Ordinary Time: Franklin and Eleanor Roosevelt, The Home Front in World War II. ${ }^{27}$ This biography carefully weaves the Roosevelts' private and public lives into one fabric, initially through what in cinematic terms would be considered a parallel projection of the German occupation of Europe in 1940 and FDR's illness with polio in 1921. Thus, the home front is consistently interpreted as "national American," on the one hand, and "domestic," that is, within the intimacy of the Roosevelts' private home, on the other. The implied claim is that the Roosevelt home is a direct reflection of America as a whole, casting the family as an inclusive allegory for the nation and all its citizens.

No Ordinary Time refers to its dramatis personae by their first names, and, like Daniel Petrie's Eleanor and Franklin biopic, it often stages Eleanor Roosevelt as narrator-perhaps because the personal, familial side of the narrative relies heavily on Eleanor Roosevelt's autobiographical writings. ${ }^{28}$ As signaled by the use of first names, the biography is intensely intimate. It infers strong links between private events in the Roosevelts' lives and public affairs of the USA's engagement in the war. The Japanese attack on Pearl Harbor, for instance, is framed in an elaborate discussion of the deaths of FDR's mother and Eleanor Roosevelt's brother in the months previous to December 7, 1941. A great deal of attention is focused on the private memories and grieving process of both Franklin and Eleanor Roosevelt. The book makes a recurrent suggestion that both worked so concertedly on preparing for the war they realized was coming, partly to alleviate their mourning, for instance, when Goodwin quotes Eleanor Roosevelt's memoir: "I think it was in an attempt to numb this feeling that I worked so hard at the Office of Civilian Defense that fall." ${ }^{29}$

The final chapter similarly links Eleanor Roosevelt's personal grief after her husband's decease, and her discovery that his extramarital relationship had been revived, to her decision to continue to bear out his political and ideological legacy. As the war ended, Eleanor Roosevelt, according to Goodwin, also made peace with the past of her troubled marriage.

For the rest of her life, her son Elliott observed, Eleanor "chose to remember only the lovely times they had shared, never the estrangement and pain." She loved to quote word for word the things they had told one another. She kept up the traditions he had established for the familyincluding the picnic on the Fourth of July and the reading of Dickens at Christmas. Maureen Corr, Eleanor's secretary during the 1940s and 1950s, remembers her "constantly talking about what Franklin did or what Franklin said or...how Franklin thought about this or that. And 
every time she mentioned his name you could hear the emotion in her voice and see the glow in her eyes."

In these first months on her own, Eleanor derived constant comfort from a little verse sent to her by a friend. "They are not dead who live in lives they leave behind. In those whom they have blessed they live a life again." These simple lines, she wrote, inspired her to make the rest of her life worthy of her husband's memory. As long as she continued to fight for his ideals, he would continue to live. ${ }^{30}$

Goodwin here interweaves Eleanor Roosevelt's public and private roles, suggesting that the constant references to "what Franklin did or what Franklin said" were motivated by her personal grief and wish to hang on to affectionate memories. The final sentence suggests that Roosevelt's motivation for continuing "to fight for his ideals" after FDR's death was to keep alive his memory. I would read this as at least also a pretext to demand attention for her own political ideals. Goodwin does include the Roosevelts' private life, and particularly Eleanor Roosevelt and the Roosevelts' marital dynamics in her discussion of American executive war leadership. However, she does not, like Enloe, expand the scope of what she regards as political by including the Roosevelts' private lives, instead treating their lives as an allegory to national events, casting "Franklin and Eleanor" as metaphorically parental figures to the nation. As a family, they are treated as premediating and personifying the USA at war, and therefore able to guide the USA through it. Goodwin does not include the private and the officious in her perception of the political, but she does treat it as a separate level that mirrors the public level of international politics, a movement that Eleanor's posing as "casually unaware of her contribution" alongside FDR in a sense makes possible.

Goodwin essentially treats the Roosevelts as a remediation of US history. She points out that they share "the sense of a cause successfully pursued through great difficulties, a theme common to America itself and to the family which guided it" (11). She implies that both the USA's and the Roosevelts' success was predicated on the greatness of the difficulties encountered and that the Roosevelts' triumph in "guiding" the USA to victory hinged on their personal experience of "great difficulties." Goodwin's phrase "the family which guided it" firmly espouses the notion that Eleanor Roosevelt took up a deputy position in leading the USA, while expanding the presidency into the private and the officious, to benefit FDR's public image as a paternal war president. 
Eleanor Roosevelt remained extremely influential after the war and her husband's death. Although she did initially lower her visibility, she held on to various ways of remediating the past and also got caught up, sometimes inadvertently, in premediating potential futures. Journalists often asked her if she would consider running for political office, including the presidency, but she continued to present herself as FDR's widow, even if her projects in reality were more her own than extrapolations of her husband's wishes. As she wrote about this in an article in Look magazine in 1948, following her refusal to run for vice-president with Harry Truman:

At first I was surprised that anyone should think that I would want to run for office, or that I was fitted to hold office. Then I realized that some people felt that I must have learned something from my husband in all the years that he was in public life! (...) The simple truth is that I have had my fill of public life of the more or less stereotyped kind. ${ }^{31}$

She continued to autofabricate her public persona as FDR's wife and suggested that fitness for political office would have to have been learned from him. Moreover, even if she continued to exert political influence, she simultaneously kept posing as someone who only reluctantly, and to her own surprise, had a public life at all.

A Gallup poll in December 1945 invited respondents to name potential candidates who "might make a good president." In this poll Eleanor Roosevelt came fourth. ${ }^{32}$ This fantasy of having her run for the highest office in the land has proved persistent, against a background of a cultural imaginary that includes very few cinematic or other projections of future female presidents. Indeed, the few premediations of potential female American presidents that there are often do cast Eleanor Roosevelt in that role. Robin Gerber's historical "what if?" novel Eleanor vs. Ike (2008) portrays an Eleanor Roosevelt who runs for president against Dwight Eisenhower in 1952 and wins, thus allowing her a position of real power in a fictional universe. ${ }^{33}$

In real life, Eleanor Roosevelt never expressed the aspiration to become president or otherwise run for political office. But despite the fact that she would probably never have had a serious chance to be nominated within the Democratic Party-because she was a woman, but also because she represented the party's radical left wing - the idea that she could have been a good candidate is easily revived by Gerber. Clearly, the Eleanor Roosevelt icon remained at hand for Gerber as a premediation of the 
potential election of Hillary Clinton to the presidency. Ellen Feldmanherself the author of Lucy (2004), a historical novel about Franklin Roosevelt's extramarital relationship with Lucy Mercer-in her appraisal called Eleanor vs. Ike "oh-so-timely" in the context of 2008, when Clinton was running for the nomination as Democratic candidate. It seems indeed that-much as Feldman's own novel about Franklin Roosevelt's affair may have been inspired by the scandal around and impeachment of Bill Clinton-Gerber offers an imagination and remembrance of Eleanor Roosevelt as a potential presidential candidate to rally support for Hillary Clinton. In the novel, Eleanor Roosevelt even encounters a five-year-old Hillary Rodham. If the novel aimed to stage a fictional premediation of Hillary Clinton's candidacy, Eleanor Roosevelt was the only historical character Gerber could have cast in the lead role. However, the novel does more than that-it draws Eleanor Roosevelt into the center of political power, a position in which it is only too easy to imagine her, especially with the benefit of hindsight.

Obviously, Hillary Clinton, too, has seen the striking parallels between herself and Eleanor Roosevelt, possibly throughout her adult life. Clinton has said on many occasions that Eleanor Roosevelt functioned as a role model and inspiration for her, and even that she tended to "talk" with her in her imagination: "[Eleanor Roosevelt] usually responds by telling me to buck up, or at least to grow skin as thick as a rhinoceros," Clinton wrote in 1995, in a weekly syndicated newspaper column, which ran from 1995 to 2000, titled “Talking It Over." It was modeled explicitly on Eleanor Roosevelt's "My Day" columns. ${ }^{34}$ Apparently, as an activist First Lady with a political agenda of her own, Clinton considered contributing to the narrative of her husband's nomos, as Eleanor Roosevelt had done, helpful and appropriate.

Nevertheless, there exists a crucial difference between Eleanor Roosevelt's and Hillary Clinton's potential space to become president after having been First Lady, even if neither happened. Eleanor Roosevelt had no serious option except to operate from the margins of the political establishment-relatively influential given that she did not hold elected office, but still marginalized - a position from which she leveraged her influence covertly. Hillary Clinton, however, has practically come to embody the Democratic establishment. Whereas male candidates for the presidency may have been strong candidates for the nomination because of their position as outsiders or politically more marginal figures, for a 
female candidate to be nominated as candidate for either of the major parties, it is vital to have ample party support.

Although the context has obviously changed, to acquire her position as a viable candidate, Hillary Clinton did use some strategies similar to Roosevelt's "casual unawareness," not in the subservient style of the frontier woman, who is truly unaware of her vital importance. Rather, like Eleanor Roosevelt, she was sharply mindful of the necessity to seem unaware and act unimposing. Especially during the 2016 presidential race, it became increasingly important that Clinton would perform a traditional gender role. Unlike male opponents, she had to smile in debates and speeches, limit modulations in her voice and gestures, and refrain from interrupting male candidates who did interrupt her. However, she did talk openly to her audience about the existence of such implicit limitations, which created space for herself and others to challenge sexism in policies and politics. She called out her opponent's coarse misogyny, while answering society's tendency to address women by their first name and men by their surname, not by emphatically asking to be called by her surname herself, but by addressing her opponent by his first name.

On the other hand, of course, Hillary Clinton neither became the Democratic nominee in 2008 nor won the presidency in 2016. There are of course many reasons why this happened, but one of those is that Clinton's gender continued to play a major role, as Trump's purely gendered slight "such a nasty woman" (October 19, 2016) attests. Even if she could, in the twenty-first century, become Secretary of State, and thus a traditional key player in foreign affairs, perhaps more so that Cynthia Enloe had considered possible, she lost the race for the presidency, despite being obviously better qualified for the role than her opponent. It seems fair to say that the lack of premediation of a female presidency played into this - it was simply hard for many voters to imagine a female president, and there were few popular cultural texts available that had familiarized them and the media with this idea. Portrayals of Eleanor Roosevelt and fantasies about how she might have filled the role of US president are among the few available templates. These fantasies, however, were perhaps less helpful to Hillary Clinton than they might have seemed, because of Eleanor Roosevelt's embrace of the language and gendered performance of domesticity and "casual unawareness." Roosevelt may have paved the way for a candidate who was a First Lady aspiring to become Commander in Chief, but eventually Clinton's assertion that she was the best and her request that voters declare themselves "\#WithHer" was far removed from 
Eleanor Roosevelt's intentionally invisible manner and her premediations of a female presidency.

\section{Notes}

1. Portions of this chapter reflect the author's views as expressed in 2007. "And with all she lived with casual unawareness of her value to civilization": Close-reading Eleanor Roosevelt's Autofabrication. European Journal of American studies, document 7. http://journals.openedition.org/ ejas/11926. doi:https://doi.org/10.4000/ejas.11926; Klemesrud, Judy. 1984. Assessing Eleanor Roosevelt as a Feminist, The New York Times, November 5.

2. Roosevelt, Eleanor. 1943. If You Ask Me. Ladies Home Journal, January 1943. The Eleanor Roosevelt Papers (Digital Edition). http://www.gwu. edu/ erpapers/IYAM/January 1943.html. Accessed December 13, 2015.

3. De Certeau, Michel. 2011. The Practice of Everyday Life, Trans. Steven Rendall. Berkeley: University of California Press, 38.

4. Roosevelt, Eleanor. My Day (Digital Edition). Accessed December $13,2015$.

5. Binker, Mary Jo, and Brigid O'Farrell. 2014. This Is What Ken Burns Neglected to Tell You about Eleanor Roosevelt. HNN.com. History News Network, 12 July 2014. http://historynewsnetwork.org/article/157795. Accessed December 13, 2015.

6. Cook, Blanche Wiesen. 1993. Eleanor Roosevelt, Vol. I, 1884-1933. New York: Penguin, 1993, 382.

7. Enloe, Cynthia. 1990. Bananas, Beaches, Bases: Making Feminist Sense of International Politics. Berkeley: University of California Press.

8. Smith, Jean Edward. 2007. FDR. New York: Random House, 199.

9. Gallagher, Hugh Gregory. 1995. FDR's Splendid Deception: The Moving Story of Roosevelt's Massive Disability and the Intense Efforts to Conceal It from the Public. St. Petersburg, FL: Vandamere Press.

10. Lash, Joseph P. 1982. Love Eleanor: Eleanor Roosevelt and Her Friends. Garden City, NY: Doubleday, 66.

11. Polak, Sara. 2015. This is Roosevelt's World - FDR as a Cultural Icon in American Memory. PhD Dissertation. Leiden: Leiden University.

12. This is analyzed in detail by David Reynolds in "FDR's Foreign Policy and the Construction of American History 1945-1955" and David Woolner in "FDR: Reflections on Legacy and Leadership, the View from 2008," both in 2008. FDR's World: War, Peace and Legacies. David Woolner, Warren Kimball, and David Reynolds, eds. New York: Palgrave Macmillan.

13. Fazzi, Dario. 2016. A Voice of Conscience: Eleanor Roosevelt and the AntiNuclear Movement. New York: Palgrave, 59; Borgwardt, Elizabeth. 2005. 
A New Deal for the World: America's Vision for Human Rights. Cambridge: Harvard University Press.

14. Roosevelt, Eleanor. 1958. My Day, February 4, 1958. http://www.gwu. edu/ erpapers /myday/displaydoc.cfm?_y=1958\&_f=md004030. Accessed December 13, 2015.

15. This argument is made, for instance, in Kearns Goodwin, Doris. 1994. No Ordinary Time: Franklin and Eleanor Roosevelt, The Home Front in World War II. New York: Simon and Schuster, 185-186.

16. Roosevelt, Eleanor. 1953. My Day, June 16, 1953. http://www.gwu. edu/ erpapers/myday/displaydoc.cfm?_y=1953\&_f=md002564. Accessed 13 December 2015.

17. Cover, Robert. 1993. Narrative, Violence, and the Law: The Essays of Robert Cover, eds. Martha Minow, Michael Ryan and Austin Sarat. Ann Arbor: University of Michigan Press, 95.

18. Reynolds, David. 2004. In Command of History, Fighting and Writing the Second World War. London: Allen Lane.

19. Black, Allida M. 1999. Courage in a Dangerous World: The Political Writings of Eleanor Roosevelt. New York: Columbia University Press, 3-4.

20. Bolter, Jay David, and Richard Grusin. 1999. Remediation: Understanding New Media. Cambridge: MIT Press.

21. Grusin, Richard. 2004. Premediation. Criticism, Vol. 46, 1: 17-39; Grusin, Richard. 2010. Premediation: Affect and Mediality After 9/11. New York: Palgrave.

22. Enloe, Bananas, Beaches, Bases.

23. Ibid., 73 .

24. Roosevelt, Eleanor. 1942. My Day. August 13, 1942. https://www.gwu. edu/ erpapers/myday/displaydoc.cfm?_y=1942\&_f=md056263. Accessed December 13, 2015.

25. Hyde Park on Hudson, directed by Roger Michell. 2012. Day Break Pictures.

26. Michaels, Beth. 2014. The Royal Hot Dog Summit of 1939. HistoryAndHeadlines.com, June 11. Accessed December 13, 2015.

27. Kearns Goodwin, Doris. 1994. No Ordinary Time: Franklin and Eleanor Roosevelt, The Home Front in World War II. New York: Simon and Schuster.

28. Eleanor and Franklin: The Early Years and The White House Years, directed by Daniel Petrie. 1977. American Broadcasting Company.

29. Kearns Goodwin, No Ordinary Time, 279-280.

30. Ibid., 633 .

31. Quoted in Steve Neal, Correspondence: 1948. Harry Truman Presidential Library Website. http://www.trumanlibrary.org/eleanor/1948.html. Accessed December 13, 2015. 
32. Beasley, Maurine H., Holly C. Shulman, and Henry R. Beasley, eds. 2001. The Eleanor Roosevelt Encyclopedia. Westport, CT): Greenwood Press, 394.

33. Gerber, Gerber. 2008. Eleanor vs. Ike. New York: Avon A.

34. Koch, Cynthia. 2016. Hillary R[oosevelt] Clinton: Or, Channeling Eleanor and Franklin. FDR Foundation (blog), September 17, 2016, http://fdrfoundation.org/hillary-roosevelt-clinton-or-channeling-eleanor-and-franklin. Accessed October 15, 2016. 